\title{
THE PERCEPTION OF ISLAMISM BY THE TEACHERS AND STUDENTS OF PESANTREN MAWARIDUSSALAM DELI SERDANG, NORTH SUMATRA
}

\author{
Dahlia Lubis \\ North Sumatra State Islamic University, Indonesia \\ E-mail: dahlialubis.uinsu@gmail.com
}

\begin{abstract}
Many studies on pesantren in Indonesia emphasize more on the aspect of this establishment as the oldest Islamic educational institution in the archipelago only, instead of other aspects related to this type of school. Recently, a growing number of studies have shifted their topic into one particular focus, which is radicalism or Islamism in pesantren. Consequently, this paper aims to examine the responses of pesantren teachers and students to the term 'Islamism'. The study was conducted at Pesantren Mawaridussalam, an Islamic boarding school located in Batang Kuis village, Deli Serdang, which is in North Sumatra, Indonesia. Specifically, the responses of teachers and students to the issue of the Islamic state were elaborated. The study also focused on shariazation, which seeks to make Islam the state law, as well as democracy, and jihād, which is a struggle or fight against the enemies of Islam the religion. The findings of this study indicate that the teachers and students had varied understandings of Islamism as some argued that the term was close to Islamists, while others believed that it was identical. Despite the different understandings, most of them rejected the use of violence in fighting for the ideals of Islam.
\end{abstract}

Keywords: Pesantren; Islamism; shariazation; democracy; jih̄id.

\section{Introduction}

Historically, pesantren is the oldest Islamic education institution in Indonesia with the main purpose to teach students the Islamic 
values and theology. ${ }^{1}$ At the beginning of its existence, the main source used to teach religious sciences in pesantren is Kitab Kuning (the yellow book, which refers to the traditional set of text used by the educational curriculum of the Islamic school) by using classic method. ${ }^{2}$ Besides classrooms and mosques, the most important element of a pesantren are the teachers usually called Kiai (which means a Javanese expert in Islam), the students often called santri, and the yellow book. Pesantren have long been perceived as an agent of the dissemination and preservation of the yellow book in the fields of faith, sharia (Islamic canonical law), worship, and mu'amalab (the traditional Islamic discipline concerned with the jurisprudence of financial transactions). ${ }^{3}$ It is undeniable that pesantren has contributed to the study and preservation of Islamic sciences in the archipelago until this time, and most of the pesantren alumni have been active in various aspects of community life in Indonesia from education, social, to political issues. Thus, pesantren has not only become the heir and successor to the treasures of Islamic sciences but has also created ulama (Islamic scholars) and scholars contributing to gaining independence and advancing the nation and Indonesia. ${ }^{4}$

Regarding its significant role, pesantren has much been studied by local as well as global researchers. The focus of their studies is relatively varied ranging from its educational approach to the religious understanding of the pesantren community. ${ }^{5}$ In this current era,

${ }^{1}$ Haidar Putra Daulay, Pendidikan Islam dalam Sistem Pendidikan Nasional di Indonesia
(Jakarta: Prenada, 2004), 63.
${ }^{2}$ Ibid., 63.
${ }^{3}$ Haidar Putra Daulay, Sejarah Pertumbuhan dan Pembaruan Pendidikan Islam di Indonesia
(Jakarta: Prenada, 2012), 61-65.
${ }^{4}$ See the discussion from: Faisal Ismail, "The Nahdlatul Ulama: Its Early History 4 See the discussion from: Faisal Ismail, "The Nahdlatul Ulama: Its Early History
and Contribution to the Establishment of Indonesian State," Journal of Indonesian Islam, Vol. 5, No. 2 (2011); Khoirun Niam, "Nahdlatul Ulama and the Production of Muslim Intellectuals in the Beginning of $21^{\text {st }}$ Century Indonesia," Journal of Indonesian Islam, Vol. 11, No. 2 (2017); M. Mujab, "The Role of Pesantren on the Development Islamic Science in Indonesia," MIQOT: Jurnal Ilmu-ilmu Keislaman, Vol. 37, No. 2 (2013). See also, Ja'far, Biografi Ketua Umum Pengurus Besar Al Jam'iyatul Washliyah (Medan: Perdana Publishing, 2015), Ja'far, Tradisi Intelektual Al Washliyah: Biografi Ulama Kharismatik dan Tradisi Keulamaan (Medan: Perdana Publishing, 2015), Dja'far Siddik and Ja'far, Al-Ittihadiyah: Delapan Dasawarsa Menerangi Nusantara (Medan: Perdana Publishing, 2017).

5 See the discussion from: Zamakhsyari Dhofier, Tradisi Pesantren: Studi Tentang Pandangan Hidup Kyai (Jakarta: LP3ES, 1982) which examines the role of Kyai in maintaining and developing traditional Islamic understanding in Java, or 
pesantren has received more attention from researchers, particularly since the emergence of some major terrorism cases in Indonesia. ${ }^{6}$ Investigations revealed that the alumni of certain pesantren were involved in the terrorism networks responsible for the terrorism attack. This fact related to pesantren alumni involvement in terrorism attack in Indonesia has somewhat caused the shift of topics of research about pesantren. Lately, studies on pesantren tend to discuss the discourse of radicalism and terrorism and the results that have been published in the form of books and articles in national and international journals share one similar theme that pesantren may be indicated as a nest for radicalism movement. To strengthen this accusation, the government of Indonesia through the National Counter Terrorism Agency (BNPT) released their findings indicating that several Islamic boarding schools were indeed indicated to be a nest of radicalism in Indonesia. However, despite this negative portrayal of pesantren, there are still many experts who assert that the accusation is not necessarily true and the indication found in some institutions is merely casuistic.

Regarding the development of radicalism in Indonesia, the State Intelligence Agency (BIN) of Indonesia released findings from the results of their research that was conducted in 2017. One of the results reveals that $24 \%$ of university students and $23.3 \%$ of senior high school students/equivalent agree to the creating of the Islamic state. This result is unfavorable as the will to create an Islamic state is often mentioned as the common reason behind a terrorism act. Another result of this research showed that $39 \%$ of university students who were the respondents in the study had been exposed to radical understanding. ${ }^{7}$ It could be concluded from these findings that radicalism has begun to grow among university and school students in Indonesia. Certainly, these findings should be a reminder for the Indonesian government and education practitioners to take an

\footnotetext{
Abdurrahman Mas'ud, Dari Haramain Ke Nusantara: Jejak Intelektual Arsitek Pesantren (Jakarta: Kencana, 2006) which examine five important Islamic scholars who are assumed to be very influential in Islamic boarding school.

6 Tasman, "al-Rādikālīyah al-Islāmīyah: Afkāruhā wa Harakatuhā fì Indūnisiyā alMuāṣir," Studia Islamika, Vol. 16, No. 1 (2009), 131-150; Jajang Jahroni, "Modernisme dan Radikalisme Islam di Indonesia: Menafsirkan Warisan Muhammad 'Abduh dan Rashid Ridha”, Studia Islamika, Vol. 11, No. 3 (2004).

7 "Komisi I Dukung BIN Awasi 3 Kampus yang Terindikasi Radikalisme," available at https://news.detik.com, 28 April 2018.
} 
effective action to prevent the seed of radicalism among Indonesian young generation grow. Furthermore, education institutions such as universities and schools or madrasah (Islamic schools) must work hand in hand with the government in tackling the growth and the development of radicalism in Indonesia.

The above findings reported by BIN might not applicable to students in pesantren. Some studies have reported that pesantren are neither involved nor have a share in the spread of radicalism and its movements in Indonesia. One of the studies conducted by Darmadji found that generally, pesantren in Indonesia could not be associated with the Islamic radical movements or thought as a new action of transnational movement. ${ }^{8}$ In line with Darmadji's findings, an American anthropologist, Ronald Lukens-Bull has also emphasized a similar point, "I have shown here that the argument that Islamic boarding schools are a source of radicalism is by and large misplaced. Islamic boarding schools have a strong history of accommodation, pluralism, and non-radicalism". ' Research by Thohir Yuli Kusmanto, et al. also revealed the same conclusion with Darmasji's and Ronald's that pesantren rejected and opposed radicalism. In contrast, the pesantren community built an anti-radicalism spirit. ${ }^{10}$ Overall, the findings of the three studies cited in this paper assert that pesantren do not play a role as a source of radicalism in Indonesia. On the contrary, they have contributed to the strengthening of Islam and nationality among their students.

Contrast with the findings of the three studies referred previously, Ayub Mursalin and Ibnu Katsir who examined the pattern of religious education in the pesantren school reported that the learning model applied in some pesantren was found effective in influencing the students' understanding of Islamic teachings which make them radical, even though the model did not lead to radical actions. ${ }^{11}$

\footnotetext{
8 Ahmad Darmadji, "Pondok Pesantren dan Deradikalisasi Islam di Indonesia," Millah: Jurnal Studi Agama, Vol. XI, No. 1 (2011), 245.

9 Ronald Lukens-Bull, "The Traditions of Pluralism, Accommodation, and AntiRadicalism in the Pesantren Community", Journal of Indonesian Islam, Vol. 2, No. 1 (2008), 14.

10 Yuli Kusmanto, et al., "Dialektika Radikalisme dan Anti-Radikalisme di Pesantren,” W alisongo: Jurnal Penelitian Sosial Keagamaan, Vol. 23, No. 1 (2015), 27-50.

11 Ayub Mursalin and Ibnu Katsir, "Pola Pendidikan Keagamaan Pesantren dan Radikalisme: Studi Kasus Pesantren-pesantren di Provinsi Jambi," Kontekstualita, Vol. 25, No. 2 (2010), 255-290.
} 
Similar findings were also reported by Abdul Malik, et al. who stated that the education culture of Pesantren al-Madinah which was the locus of research has a tendency towards radicalism and exclusivism. The education culture in the Islamic boarding school also leads to a jibäd curriculum. ${ }^{12}$ Thus, referring to these two studies, it could be hypothesized that the curriculum used in a pesantren indirectly has the potential to be a source of the spread of radicalism, even though it does not lead to terrorism.

In studies investigating issues in pesantren, the topic of radicalism is more often discussed than the topic of Islamism. Only recently, some researchers show their interest in that topic by conducting studies to examine pesantren and the issue of Islamism. ${ }^{13}$ Among them is Abd A'la's study which examined the organization of the Aliansi Ulama Madura (AUMA) and the Forum Kiai Muda Madura (FKM) ${ }^{14}$ in organizing the masses by forming layered sectarianism. ${ }^{15}$ Another

12 Abdul Malik, et al., "Kultur Pendidikan Pesantren dan Radikalisme," Jurnal Pembangunan Pendidikan: Fondasi dan Aplikasi, Vol. 4, No. 2 (2016), 103-114.

13 The studies about Islamism has been conducted in Indonesia, for example Hans Abdiel Harmakaputra, "Islamism and Post-Islamism: "Non-Muslim" in SocioPolitical Discourse of Pakistan, the United States, and Indonesia," al-Jami'ah: Journal Islamic Studies, Vol. 53, No. 1 (2015), Masdar Hilmy, "The Politics of Retaliation: the Backlash of Radical Islamists to the Deradicalization Project in Indonesia," alJami'ab: Journal Islamic Studies, Vol. 51, No. 1 (2013), Masdar Hilmy, "Konstruk Teologis Islamisme Radikal di Indonesia Pasca-Orde Baru," MIQOT: Jurnal Ilmuilmu KeIslaman, Vol 32, No 1 (2008); Abd A`la, Mukhammad Zamzami, Nur Hidayat Wakhid Udin, Ahmad Fathan Aniq, "Islamism In Madura: From Religious Symbolism to Authoritarianism", Journal of Indonesian Islam, Vol. 12, No. 2 (2018). For study in North Sumatra, has been conducted by Faisal Nurdin who writes "Memetakan Narasi Islamisme di Medan, Sumatera Utara: Investigasi terhadap Pola Penyebaran dan Penerimaan terhadap Radikalisme," Jurnal Ilmu Politik dan Komunikasi, Vol. 5, No. 2 (2015), Ja'far, "Perkembangan Politik Islamisme Moderat Al Jam'iyatul Washliyah", Al-A'raf: Jurnal Pemikiran Islam dan Filsafat, Vol. 16, No. 2 (2019); Ja'far, “Al Jam'iyatul Washliyah dan Ideologi Islamisme di Indonesia," in Moch. Nur Ichwan and Muhammad Wildan (eds.), Islamisme dan Pos-Islamisme dalam Dinamika Politik Indonesia Kontemporer (Yogyakarta: SUKA-Press, 2019), 369-410.

14 Abd A'la, Ahwan Mukarrom, Mukhammad Zamzami, "Kontribusi Aliansi Ulama Madura (AUMA) dalam Merespons Isu Keislaman dan Keumatan di Pamekasan Madura", Religió: Jurnal Studi Agama-agama, Vol. 8, No. 2 (2018), Abd A'la, Ahwan Mukarrom, Mukhammad Zamzami, "Islam dan Agamaisasi Politik: Studi Analisis terhadap Peran dan Pergerakan Forum Kiai Muda (FKM) Pamekasan Madura", Jurnal Review Politik, Vol. 8, No. 1 (2018).

15 Mukhammad Zamzami, "Kontribusi Forum Kiai Muda (FKM) Madura dalam Membangun Islamisme di Pamekasan", Proceeding of the International Conference on Muslim Society and Thought, 3-4 October 2017, Surabaya, Indonesia (2017). 
study was conducted by Atmari who studied Islamism and postIslamism which is still held by the kiai as an Islamic boarding school intellectual while at the same time highlighting the views of pesantren leaders. ${ }^{16}$ A study by Nur Kafid explored the shifting orientation of the radical Islamic group movement during the democratic decentralization and the factors influencing it. ${ }^{17}$ Meanwhile, Rendy Adiwilaga tried to uncover the dynamics of the Islamism movement in Indonesia starting from the Islamic Union (SI), Darul Islam (House of Islam), Masyumi Party (Council of Indonesian Muslim Association), to the Islamic Defenders Front (FPI). ${ }^{18}$ Hasan Baharun and Rabiatul Awwaliyah examined the handling of narratives of Islamism in Indonesia through multicultural education. ${ }^{19}$ Another study conducted by Nuruddin Al Akbar examined the efforts of Islamist groups to fight for the application of Islamic law. ${ }^{20}$ Finally, Ai Fatimah and Nur Fuad tried to map the Tarbiyah (Character Education) movement in the religious, social, economic and political fields in Indonesia since the 1980s. ${ }^{21}$ However, despite the growing number of researches investigating Islamism in pesantren, very few (or perhaps none) tried to explore the responses of a pesantren community to the topic of Islamism which currently becomes an issue in the academic realm, especially for teachers and students in Islamic boarding schools.

Considering the gap mentioned earlier, this article seeks to explore the Islamic boarding school community's response to Islamism that is now prevalent in Indonesia. Specifically, this research

16 Atmari, "Post-Islamism Kyai: Memantapkan Nalar dan Sikap Islamisme ala Intelektual Pesantren," in 2nd Annual Conference for Muslim Scholar Proceedings, 2018.

17 Nur Kafid, "Dari Islamisme ke Premanisme: Pergeseran Orientasi Gerakan Kelompok Islam Radikal di Era Desentralisasi Demokrasi," Masyarakat: Jurnal Sosiologi, Vol. 21, No. 1 (2016).

18 Rendy Adiwilaga, "Gerakan Islam Politik dan Proyek Historis Penegakan Islamisme di Indonesia," Jurnal Wacana Politik, Vol. 2, No. 2 (2017).

19 Hasan Baharun and Rabiatul Awwaliyah, "Pendidikan Multikultural dalam Menanggulangi Narasi Islamisme di Indonesia," Jurnal Pendidikan Agama Islam, Vol. 5, No. 2 (2017).

${ }^{20}$ Nuruddin Al Akbar, "Probabilitas Syariatisasi Negara Paska Orde Baru: Berkaca dari Strategi Kelompok Islamis Memperjuangkan Pengesahan RUU APP," Jurnal Sosiologi Islam, Vol. 3, No. 2 (2013).

${ }^{21}$ Ai Fatimah and Nur Fuad, "Islamisme dan Dakwah di Indonesia: Perspektif dan Pengalaman Dakwah Gerakan Tarbiyah," Komunika: Jurnal Komunikasi, Vol. 10, No. 1 (2015). 
discusses how the understanding of teachers and students of a pesantren on the issues considered the indicators of Islamism, namely the state, sharia, and democracy; secularization, pluralism, and liberalism; jihadists, infidels and Jews. These indicators are used to show Islamism. Specifically, this study used criteria introduced by Bassam Tibi $^{22}$ through five characteristics of Islamism, namely: 1) Unity of religion and state; 2) Jews as enemies of Muslims; 3) The evolution of classical jihadism into jihadism terrorism; 4) Shariazation of state law, and 5) Discourse on purification and authentication (rejection of westernization). However, not all indicators of Islamism will be used in the discussion. This study merely focuses on examining the understanding of pesantren teachers and students about the Islamic state, sharia, democracy, jihäd, and non-Muslims.

Methodologically, this study is the result of field research. Data obtained from questionnaires and interviews with the participants who were the teachers and the students of Pesantren Mawaridussalam. The questionnaire was distributed to gain the data needed to map the responses of the teachers and the students related to the understanding of Islamism. Furthermore, the results of the data collected through the questionnaire were used to guide the researcher in creating questions asked in an interview session, which functioned twofold; first, to dig deeper information about the topics of discussion, and second to validate or invalidate the unclear information gathered from the first instrument. Twelve teachers and 28 twenty-eight students were asked to fill the questionnaires and were interviewed by the researcher. Through the distributed questionnaire, teachers and students were asked to give a choice whether to agree or disagree with the idea of establishing an Islamic state; making Islamic sharia as a law in Indonesia; democracy is part of the teachings of Islam; the meaning of jihäd is only fighting the infidels and the polytheists; Jews and Israel are enemies of Muslims; legalizing suicide bombings; and acceptance of the group of ideas of secularism, liberalism and pluralism; lesbian, gay, bisexual, and transgender; Ahmadiyya, Shia, denomination of beliefs; and women as leaders. This research was conducted in the 2016/2017 school year. The data obtained were reduced, presented, and deduced.

22 See Bassam Tibi, Islam and Islamism (London: Yale University Press, 2012), 1-30. 


\section{The Profile of Pesantren Mawaridussalam}

In the region of North Sumatra, several Islamic boarding schools have been established and developed, among them are Pesantren Musthafawiyah, Pesantren al-Kautsar, Pesantren al-Akbar, and Pesantren Raudlatul Hasanah. A number of studies have been conducted to investigate Islamic boarding schools in North Sumatra. However, none have discussed the understandings developed in Islamic boarding schools, not to mention to relate them to Islamism. For this reason, this research aimed to explore how pesantren teachers and students, particularly those of Pesantren Mawaridussalam respond to Islamism.

The establishment of Pesantren Mawaridussalam was initiated by five Pesantren Gontor alumni, Syahid Marqum, Basrin Sudarmanto, Junaidi, Maghfur Abdul Halim, and Abdul Wahid Sulaiman. Pesantren Mawaridussalam is located in Batang Kuis village, Deli Serdang District, North Sumatra, Indonesia. The pesantren was named Mawaridussalam in 2008 with the hope that it would be a source of peace, safety, and happiness. The establishment of this pesantren was approved by the Ministry of Law and Human Rights on November 18, 2010, which was symbolized with the groundbreaking of the female student dormitory and witnessed by local community figures, including those from the Indonesian Ulama Council (MUI) of North Sumatra, Indonesian Ulama Council (MUI) of Deli Serdang, Regional House of Representative (DPRD) of Deli Serdang Regency, and Indonesian Malay Cultural Council (MABMI) of Deli Serdang Regency. There were no less than six hundred people attended this event. From the personnel aspect, the founders and some teaching staff of this pesantren were Pesantren Gontor alumni. Officially, the admission of new students to this pesantren was started in 2010. Thus, Pesantren Mawaridussalam with its motto "Pesantren Mawaridussalam founded on and for all groups" ${ }^{, 23}$ has been established for ten years.

Pesantren Mawaridussalam has a particular organizational structure consisting of two main units. First, Nadzir Waqf (the unit holding the mandate to take care of the endowment given to the pesantren), as the highest position in the institution organization. The position of this unit could be analogized as that of a legislature that has the function of a waqf holder and plays a role as guardian and

\footnotetext{
23 "Sejarah Pendirian Ponpes Mawaridussalam," http://mawaridussalam.ponpes.id /sejarah-pendirian, diakses 12 September 2018.
} 
preserver of the waqf belonged to this pesantren. Second, the Leadership Council as the mandate of Nadzir Waaf responsible to oversee the implementation and development of teaching and learning in this pesantren. This unit of Leadership Council could be regarded as an executive body consisting of five members. In addition to the said responsibility, this unit also manages some sub-units and takes part in nurturing the students to keep them in line with the pesantren sunnah. There are six sub-units managed by the Leadership Council. First, the education sub-unit with the role of coordinating the implementation of teaching through the programs of Kulliyatul Mu'allimin alIslamiyah (KMI), Islamic Junior High School (MTs), Islamic Senior High School (MA), Labikif, Language Laboratory, and Early Childhood Education (PAUD). Second, the caring sub-unit responsible for taking care of the students, especially in extra-curricular activities. This sub-unit comprises several bureaus. Third, the research and development sub-unit consisting of four bureaus, namely: Interest and Talent Development (PMB), Library, Syllabus, and regeneration. Fourth, the well-being sub-unit dealing with the well-being of teachers, students, and employees. This unit has two bureaus; the Development Bureau and the Consumption and Health Bureau responsible for managing the Students and Community Medicine Centers (BPSM). Fifth, Business Field Owned by Pesantren (BUMP) sub-unit which is responsible for managing all business units owned by the Islamic boarding school, either managed by students or the teachers. Sixth, the unifying alumni sub-unit field, which is also named the Association of Pesantren Mawaridussalam Family (IKMAS). ${ }^{24}$

\section{The Discourses of Islamic State, Sharia, and Democracy}

According to Bassam Tibi, $^{25}$ the Islamist community emphasizes the unity of religion and state. However, the Islamists not only aim to remake the political order of the territorial state but also to create a new world order. According to Tibi, Islamism tries to change Islamic universalism into political internationalism and replace the concept of the nation-state with the Islamic system. The side impact of this idea is that the Islamists support the application of

24 "Struktur Organisasi di Pondok Pesantren Mawaridussalam," http://mawaridussalam.ponpes.id/struktur-sekolah. Diakses 12 September 2018.

${ }_{25}$ Bassam Tibi, Islam dan Islamisme, terj. Alfathri Adlin (Bandung: Mizan, 2016), 4, 24, 43-44. 
sharia law in a country. Their objective is to create an Islamic sharia state even though it does not necessarily mean a caliphate, an Islamic state under the leadership of an Islamic steward called 'Caliph'. Regarding democracy, jihadis Islamists reject the system of democracy, while institutional Islamists use democracy as a modern instrument and procedure, but they reject the political philosophy and culture of democracy because they are considered to originate from the West.

Previous studies on Islamic boarding schools indicate that kiai (teacher) and santri (student) are the two main elements of a pesantren, in addition to the dormitory, mosque and yellow book. The classical books are taught and preserved through pesantren, thus the religious understanding of the kiai and santri is more or less shaped by the teachings contained in the yellow book. For this reason, it is interesting to see how the understanding of the pesantren teachers as the object of the research related to Islamism. Particularly, their understanding of the discourses of state, sharia and democracy need investigation as one of the most important understandings of Islamist groups in the world, and their relationship also needs assessment with the beliefs of Islamist groups.

A number of Islamic groups in Indonesia are intensely discussing state enforcement and Islamic law and some of them are radical hardliners. As what Zada claimed that there are some hardline Islamic organizations that have radical thoughts such as Front Pembela Islam (Islamic defenders Front/FPI), Warriors of Jihad of Ahlussunnah Waljamaah, and Indonesian Council of Mujahideen and Indonesian Committee for Islamic World Solidarity (KISDI). These organizations support the establishment of Islamic law and Indonesia as an Islamic state. For this purpose, they have mobilized the movement in the field of da'wah and politics. ${ }^{26}$ However, some of those groups have no longer fought for an Islamic state in Indonesia because they consider it could disintegrate the unity of the state while they know that the Unitary State of Indonesia (NKRI) is final. Nevertheless, they continue to fight for the enforcement of Islamic law in Indonesia. For instance, it was carried out by Muslim-based

\footnotetext{
${ }^{26}$ Khamami Zada, Islam Radikal: Pergulatan Ormas-ormas Islam Garis Keras di Indonesia (Jakarta: Teraju, 2003).
} 
mass parties. Some regions even impose Islamic Sharia regional regulations such as in Aceh. ${ }^{27}$

\section{The Response of the Pesantren Teachers}

Based on the analysis of the data collected from the questionnaire and interview, it was found that most of the teachers ( $\mathrm{n}$ $=11$ ) agreed with the idea of establishing an Islamic state. There are at least two reasons for them. First, Islam is a perfect religion that covers all aspects of human life. Islam not only discusses the issue of faith and worship but also the details of the country's issue. Second, if an Islamic state is not established, Islamic law will be difficult to apply in the Muslims life as what a teacher said in the following excerpt:

"With an Islamic state, a country's rules and laws will automatically follow Islamic law. This is necessary considering that Indonesia is currently experiencing a moral crisis. Islam is a perfect religion in the field of law. All problems have been determined, moreover to the smallest things". 28

However, another teacher showed his disagreement with the idea of an Islamic state because it may lead to the hostility of religions. Furthermore, he believed that Indonesian society has Pancasila as the basis of the state and the unifying glue for the nation which comes from a variety of tribes, nationalities, and religions as seen in the following excerpt:

"The idea of establishing an Islamic state could lead to hostility with other religions in Indonesia, especially since Indonesia has already had a mutually agreed state guideline namely Pancasila". ${ }^{29}$ Thus, most of the teachers have a tendency to be Islamic, because Islamism assesses that the state and religion are one unit.

27 Taufik Adnan Amal and Syamsu Rijal Panggabean, Politik Syariat Islam: dari Indonesia bingga Nigeria (Jakarta: Pustaka Alvabet, 2004), 9; Hamdan Juhannis, “The Struggle for Formalist Islam in South Sulawesi: From Darul Islam (DI) to Komite Persiapan Penegakan Syariat Islam (KPPSI)," (PhD Thesis--Australian National University, 2006); Firman Noor, "Moderate Islamic Fundamentalism: Understanding the Political Thinking of the Partai Keadilan Sejahtera (PKS)," Studia Islamika, Vol. 14, No. 3 (2007); Firman Noor, "Leadership and Ideological Bond: PPP and Internal Fragmentation in Indonesia," Studia Islamika, Vol. 23, No. 1 (2016).

${ }^{28}$ Interview with Azra Siltio (Mawaridussalam Islamic Boarding School Teacher) at Batangkuis on 8 August 2018.

29 Interview with Mufidatul Husna (Mawaridussalam Islamic Boarding School Teacher) at Batangkuis on 18 June 2018. 
Regarding the discourse of shariazation, most of the teachers (n $=7$ ) agreed with the idea of implementing Islamic law as the law in Indonesia. They stated several reasons which include the benefits of Islamic law for Indonesia. In addition, some of them consider that Islamic law is the perfect and best regulation compared to regulations made by human beings since Islamic law has governed all human matters, not only regulating human relations with God but also with other humans and with their natural surroundings. On the contrary, five teacher participants disagreed if Indonesia applies Islamic law. They reasoned that even though Muslims are the majority population in Indonesia, the citizens of this country are not only Muslims, but also Catholics, Protestants, Hindus, Buddhists, and Confucius. There are also those who argued that laws in Indonesia do not conflict with Islamic law, thus it is not necessary to be replaced with Islamic law. Furthermore, they emphasized that Indonesia is not founded based on Islamic religion but Pancasila as what a participant said:

"The basis of the Indonesian state has been established, namely

Pancasila and the 1945 Constitution which asserted that every Indonesian citizen has the right to choose their religion and beliefs so that the enforcement of Islamic law no longer needs to be fought for". 30

However, the results still indicate that most of the teachers are Islamists because they accept the idea of making Sharia as official regulation in Indonesia.

Related to the topics of Islam and democracy, four teachers who agreed to establish the Islamic State and the enforcement of Islamic law emphasized that they do not agree with the democratic system and Islam is not in accordance with democracy. They also believed that democracy originates from the Western world, and merely underlies the truth of the majority group's vote, in fact, the truth is not only determined by the majority group. One teacher disagreed with democracy because of the idea that "this system only looks at who has more supporters and voters". ${ }^{31}$ On the other hand, the majority of teachers agreed with the democratic system and believed that there is no conflict between Islam and democracy. Those who agree with the system of democracy applied in Indonesia

\footnotetext{
${ }^{30}$ Ibid.

31 Interview with Azra Siltio (Mawaridussalam Islamic Boarding School Teacher) at Batangkuis on 8 August 2018.
} 
stated the following "Islam supports democracy as leaders of a country that adheres to an honest and responsible democracy". ${ }^{32}$

Based on the results of the data analysis, it can be concluded that the majority of teachers in Pesantren Mawaridussalam share the same understanding as institutional Islamist groups that accept democracy even though it is merely used as a tool to achieve some specific purposes. On the contrary, the minority of them have the same understanding with the jihadist Islamists who reject democracy because it is considered to come from the secular Western world.

Although the majority of the teachers agreed with the democratic system, they rejected the existence of minority groups in Indonesia. For some examples they reject the existence of lesbian, gay, bisexual and transgender (LGBT) community; the denomination of Ahmadiyah, Shi'sah, and other schools of thought in Indonesia that they perceived distorted form the real Islamic teachings; and secularism, pluralism, and liberalism as seen in the following statement by one of the participants:

"LGBT violated the Creator's decree. All creatures were created in pairs, unnatural actions, and shameful deeds. Besides, Ahmadīyah and Shī'ah are declared heretical. For local religions, such as Parmalim, it is unfortunate that as Muslims, they still maintain the original religion that emerged in Indonesia". ${ }^{33}$

Another teacher shared a similar opinion by stating:

"LGBT is a futile behavior, an act of sin and establishing the wrath of God. For Shīah, Indonesian Muslims must be alert because Shīah is a major disaster for Islam, moreover, this denomination is damaging Islamic law through the teachings of their school". ${ }^{34}$

Regarding the topic of women as leaders, two teachers refused the idea of women as leaders of a country, while ten teachers believed the opposite that women may be leaders in a country. The rejection of women as leaders is not only from male teachers but also from the female ones. Whereas all teachers who accept female leadership are male.

\footnotetext{
32 Interview with Emsi Mawarisa Ginting (Mawaridussalam Islamic Boarding School Teacher) at Batangkuis on 18 June 2018.

${ }^{33}$ Interview with Azra Siltio (Mawaridussalam Islamic Boarding School Teacher) at Batangkuis on 8 August 2018

34 Interview with Denni Karo-karo (Mawaridussalam Islamic Boarding School Teacher) at Batangkuis on 7 June 2018.
} 
Finally, regarding secularism, pluralism, and liberalism, ten teachers reject the three concepts, and as many as two teachers do not question it at all. Their rejection of minority groups in Indonesia shows an attitude of inconsistency. On the one hand, the majority of them accept democracy, but on the other hand, they reject the existence of minority groups who should have the same opportunities as the majority one in a democratic country.

\section{The Response of the Pesantren Students}

Regarding the issues facing by the nation, the majority of the pesantren students $(\mathrm{n}=25)$ expressed their agreement with the idea of establishing an Islamic state. For some of them, the rationale behind their agreement is because Islam is the truest and most perfect religion. Islam not only discusses the issue of faith and worship but also mu'amalah and politics. Some of them stressed that without the establishment of an Islamic state, Islamic law would not be possible to implement in Indonesia. For a small number of students, the Islamic state is a solution for the progress and development of Muslims. Therefore, there are some students who support the caliphate. Through an Islamic state, some students believe that Muslims will be able to surpass the Western world, which is mostly dominated by atheists, Christians, and Jews as pictured in the following quotes:

"The caliphate has proven successful in making Muslims victorious in the past"; 35

"If an Islamic state has been established, then Muslim society will gain glory"; 36

"Through the Islamic state, the government system and applicable regulations will be in accordance with Islamic law". ${ }^{37}$ "Islam is the true religion, and with the establishment of the state with Islamic principles, people will be on the right path according to Islamic law provisions". ${ }^{38}$

\footnotetext{
35 Interview with Sivliana (Mawaridussalam Islamic Boarding School student) at Batangkuis on 23 March 2018.

36 Interview with Syahreza Pahlevi (Mawaridussalam Islamic Boarding School student) at Batangkuis on 17 March 2018.

37 Interview with Mhd. Latifudzikri and Agung Ilham Syahputra (Mawaridussalam Islamic Boarding School student) at Batangkuis on 20 March 2018.

38 Interview with Ana Nur Annisa (Mawaridussalam Islamic Boarding School student) at Batangkuis on 20 March 2018.
} 
Out of the 28 student participants, three of them rejected the establishment of an Islamic state. They reasoned that some countries that claim to be Islamic countries also face similar problems as those that are not Islamic based, therefore, the foundation of the state does not determine the progress of a nation and state as said by a student quoted here:

"Many Islamic-based countries have been established but face the same problems as a state that is not based on Islam". ${ }^{39}$

Thus, the understanding of the majority of the pesantren students is closer to Islamism which asserts that Islam and the state cannot be separated, so the idea of an Islamic state still needs to be fought for.

Related to the discourse of shariazation of the nation, the majority of the pesantren students $(n=20)$ agreed with the idea of making Islamic sharia (the fundamental religious concept of Islam) as a law in Indonesia. According to them, Islamic law will be able to bring the country to goodness, justice, and prosperity. Some students consider that the laws and regulations in Indonesia should not be mixed with secular Western laws because the majority of Indonesia's population adheres to Islam. Some other pesantren students added that Islamic law is derived from God's perfect revelation, while Western law comes from a human's limited mind. Some students added that laws which are based on Islamic law will help create an Islamic lifestyle of society as said by one of the students,

"By making Islamic Sharia law in Indonesia, the Indonesian

people would be able to go the way of Allah, the real way".

However, there are also some pesantren students $(\mathrm{n}=8)$ who refused the idea of implementing Islamic Sharia as the law in Indonesia. They reasoned that the population in the country of Indonesia comprises various ethnicities, nationalities, religions, and beliefs. If the Islamic Shari'a is adopted as a law, it may bring about divisions for this plurality of Indonesian population as what the following participants said,

"Islamic law does not need to become law in Indonesia, because not all Indonesian people adhere to Islam;" 41

\footnotetext{
39 Interview with Hamid (Mawaridussalam Islamic Boarding School student) at Batangkuis on 17 March 2018.

40 Interview with Ana Nur Annisa (Mawaridussalam Islamic Boarding School student) at Batangkuis on 17 March 2018.

41 Interview with Syahreza Pahlevi (Mawaridussalam Islamic Boarding School student) at Batangkuis on 17 March 2018.
} 
"Laws in Indonesia have considered the values of Islamic teachings." 42

Based on these findings, it could be concluded that both pesantren students and teachers share a similar understanding of Islamism related to the issue of sharization of state regulations.

Although the pesantren students accepted the idea of establishing an Islamic state and making Islamic Sharia law, the majority of them $(n=19)$ support the democratic system and emphasize that there was no conflict between Islam and democracy. They considered that democratic values such as justice, equality and freedom are in accordance with the principles of Islam. However, some of them clarified that their acceptance of the democratic system did not necessarily mean that they agreed with Western democracy which justifies secularism. They furthermore explained that their acceptance of democracy applies only applied if the democratic principles are in accordance with Islamic teachings. Meanwhile, a total of nine students rejected the democratic system because, for them, democracy comes from the results of human thought and comes from the secular Western world. According to them, in the democratic system, power is in the hands of the people, whereas in Islam the power belongs to God. Thus, the legal source of a country that adopts a democratic system comes from the human mind, while the source of the law should be God's revelation.

Regarding the issues concerning minority groups, although the majority of the student participants accepted the democratic system and considered it in line with Islamic teachings, all students rejected the existence of LGBT groups, and the legalization of LGBT is a form of neglect to Islamic teachings as seen in the following excerpt:

"In fact such a thing (LGBT) will damage the next generation of

Muslims, and such behavior is inappropriate for people who understand Islam". 43

This rejection was also indicated by another student quoted here, "LGBT behavior has been forbidden by Islamic Sharia." 44

\footnotetext{
42 Interview with Hamid (Mawaridussalam Islamic Boarding School student) at Batangkuis on 17 March 2018.

43 Interview with Agung Ilham Syahputra (Mawaridussalam Islamic Boarding School student) at Batangkuis on 20 March 2018.

${ }^{44}$ Interview with Abdul Latif (Mawaridussalam Islamic Boarding School student) at Batangkuis on 20 March 2018.
} 
Regarding the issues of minority groups that belong to different schools of thought, there are four pesantren students who did not dispute the presence of Ahmadiyah followers in Indonesia, while the majority of them rejected the particular school of thought or sect. Those who rejected Ahmadiyah considered that the teachings of the sect far exceed the limits of the real teachings of Islam, thus they are not in accordance with the teachings of Koran and Hadith. This denomination is heresy and has been banned by Islamic scholars. Their rejection is indicated in the following excerpts, "the Ahmadiyah denomination is heretical and misleading;" 45 and "the Ahmadiyah corrupts the Islamic Sharī'ah." ${ }^{-46}$

All Islamic boarding school students reject Shīah and consider it as heretical denomination and deviate from the teachings of the Prophet Muhammad as found in this excerpt, "Shi' $a$ ah teaches false teachings and deviates from the teachings of the Apostles." Meanwhile, regarding the concept of secularism, pluralism, and liberalism, most of them rejected them. Finally, regarding the issue of women leadership, two male and one female student did not oppose the idea of a woman becoming the head of a state, while the majority rejected the leadership of women in a country.

These results, similar to those of the teachers, indicate inconsistencies in the opinion of the majority of the students, where they accept democracy but reject the minority groups in Indonesia. In fact, recognition of democracy requires the acceptance of minority groups.

\section{Issues of Jihād and Non-Muslim}

Bassam Tibi $^{48}$ considered that Islamists made jih äd as a means to change the new world order based on Islamic teachings. However, they do not mean jihäa in the sense of real jibäd according to classical scholars, they present a new meaning for jibäd. Therefore, the classical meaning of the term jihäd has evolved into a new meaning of modern jihadism. The meaning of classical jihäd applies when war is declared by the caliphate, however, for Islamists, jihäd is played by non-state

\footnotetext{
45 Interview with Annisa Rafika (Mawaridussalam Islamic Boarding School student) at Batangkuis on 24 March 2018.

46 Interview with Mhd. Latifudzikri (Mawaridussalam Islamic Boarding School student) at Batangkuis on 20 March 2018.

${ }^{47}$ Ibid.

48 Tibi, Islam dan Islamisme, 176-187.
} 
actors. Against non-Muslims, Islamists have the belief that Jews are their main enemies conspiring to fight the Islamic world.

The terms jibäd, infidels and polytheists are repeatedly mentioned in Qur'ān and Hadīth. The Islamists make the terms jïhäd and Jewish two of the themes of their discussion, in which they redefine the term jibäd and perceive the Jewish as the main enemy of the Islamic world. In this section, the understanding of the pesantren teachers and the pesantren students is focused on the issue of jib äd and non-Muslims, and their relationship will be assessed with the beliefs of Islamist groups.

All this time, most researchers have carried out their studies focusing on the topics of jibäd and non-Muslims and linked them to the issue of radicalism in Indonesia. Thus, it is necessary to advance the discussion on the meaning of jibäd in Islam, its relation to terrorism, and suicide bombings. Some studies also focused on some Islamic movements in Indonesia, conducted in the name of jihäa. ${ }^{49}$ Lukman Areke, for example, discusses the meaning of jibäd in Islam because there is an assumption from the non-Muslim community that Muslims are the spreaders of terror and terrorism in the world through the application of the concept of jihäd. Areke's study found that non-Muslim groups had misunderstood the meaning of jibād as a result of ignorance and intentionality. ${ }^{50}$ Regarding suicide bombings, there are some movements that reject suicide bombings while some others accept it. Rusli who conducted a research on jibäd and suicide bombings based on Salafism in Indonesia found that Wahabi Salafi groups disagree with suicide bombings, while Salafi Jihadists support suicide bombings. ${ }^{51}$

${ }^{49}$ Din Wahid, "Pentas Jihad Gerakan Salafi Radikal Indonesia," Studia Islamika, Vol. 14, No. 2 (2007); Amiq, "Two Fatwas on Jihad Against the Ducth Colonialization in Indonesia: A Prosopographical Approach to the Study of Fatwa", Studia Islamika, Vol. 5, No. 3 (1998); Sukidi Mulyadi, "Violence under the Banner of Religion: The Case of Laskar Jihad and Laskar Kristus," Studia Islamika, Vol. 10, No. 2 (2003); Olaf Schumann, "Jihad for Whom?: The Radicalization of Religion as a Response to Political Oppression: From Turkish to Indonesian Islam," Journal of Indonesian Islam, Vol. 2, No. 2 (2008).

50 Lukman Areke, "Pendekatan Hukum Islam terhadap Jihad dan Terorisme," Ulumuna: Journal of Islamic Studies, Vol. 16, No. 1 (2012).

${ }^{51}$ Rusli, "Indonesian Salafism on Jihad and Suicide Bombings," Journal of Indonesian Islam, Vol. 8, No. 1 (2014). 


\section{The Response of the Pesantren Teachers}

The results of the data analysis show that seven pesantren teachers agreed that jibäd meant fighting the infidels. One of them argued that jiba $\bar{d} d$ really meant fighting a war against the infidels who were hostile to Muslims. However, the word 'war' here was not literally interpreted as physical war, but against the infidels' domination of the world, for example, their dominance in politics, science, technology, and education, as could be understood from this excerpt:

"Jihad in the sense of fighting is not the real war, but fighting the domination of the infidels in their role in the current era in the fields of education, politics, science, and technology". ${ }^{2}$

In contrast with this understanding of the meaning of jibadd, some other teachers out of the seven understood the term as a physical war to fight the infidels who are hostile to Muslims. This, according to them, is the real jih äd in the way of Allah, as explained in the Quran. Very few teachers who understood jih $\bar{a} d$ radically believed that fighting the polytheists is a good deed, thus their blood is lawful to be shed. While others who also believed that one of the meanings of jibäd had a different understanding, which does not merely mean war against them, but being persistent in doing righteousness.

The results also show that some teachers $(n=5)$ understood jihäd not only as fighting the infidels and the polytheists, but also to fight oneself. They considered that jibäd was not only directed to the polytheists, but also towards themselves and the Islamic renunciation. In addition to this understanding, they also believed that jibäd is to fight in the way of Allah. This means that all good deeds done by a Muslim should be with the intention of surrender to God then these actions could be considered as jihäd. Some teachers also added that jihäd did not mean fighting, but defending themselves from the infidels and the polytheists who are hostile to Muslims as stated by one of the participants,

"Jihäd is fighting, and this jïhäd varies as jibäd for oneself, for religion, and includes fighting infidels who are hostile to and disturbing Islam". ${ }^{53}$

\footnotetext{
52 Interview with Glen Sofyan (Mawaridussalam Islamic Boarding School Teacher) at Batangkuis on 21 March 2018.

53 Interview with Denni Karo-karo (Mawaridussalam Islamic Boarding School Teacher) at Batangkuis on 7 June 2018.
} 
Another teacher shared a similar opinion, "Jihäd is fighting in the way of Allah. Jibäd has broad meaning, not only war. Learning also includes jihadd'. ${ }^{54}$ These results indicate that the pesantren teachers understand jibäd according to classical Islamic scholars' interpretation, this is not identical with that of Islamist groups who redefine the term jibäd.

Regarding the topic related to non-Muslim, particularly Jews and Israel, all teachers who were interviewed agreed that Jews and Israel are the enemies of Muslims. Some of them stated that history has recorded racist attitude of the Jewish and Israel as a nation that has long oppressed the Palestinian. For some teachers, the holy Quran has explicitly explained that Jews will never be happy with Muslims. They also think that the main mission of the Jews and Israel is to destroy Muslims and Islamic teachings from the world as seen in these excerpts:

"It is clearly said in the Koran that Jews and Israel will never be happy to see Islam on this earth". ${ }^{55}$

"The Jewish savagery of Palestinian Muslims shows that they are enemies of Muslims". 56

Thus, it could be concluded that the teachers of Pesantren Mawaridussalam had a similar understanding with that of Islamists regarding the issue of Jews as enemies of the Islamic world.

Finally, regarding the issue of terrorism which is often associated with the understanding of jib äd in fighting non-Muslims, the teachers explicitly reject the doctrine of suicide bombing as the most common act of terror. Some of them considered the terrorist group who carried out suicide bombings had misunderstood the meaning and the concept of jibäd in Islam. They believed that suicide bombing is a form of violation of Islamic rules, and is an act against humanity. Thus, suicide bombers will never reach the status of Shabeed (a Muslim martyr) and enter heaven, instead, they will stay in hell. Moreover, in many cases, the victims of suicide bombings are innocent people, who were not the real target of the terrorism act itself. Some teachers even believed that suicide bombers die in the

\footnotetext{
${ }^{54}$ Interview with Azra Siltio (Mawaridussalam Islamic Boarding School Teacher) at Batangkuis on 8 August 2018.

55 Interview with Denni Karo-karo (Mawaridussalam Islamic Boarding School Teacher) at Batangkuis on 7 June 2018.

56 Interview with Glen Sofyan (Mawaridussalam Islamic Boarding School Teacher) at Batangkuis on 21 March 2018.
} 
condition of fäsiq (violating Islamic law) as stated by the following participants:

"This action (suicide bombing) has violated religious rules, especially Islam"..$^{57}$

"Suicide bombings are prohibited because many innocent people are affected. Islam never teaches its people to go beyond their limits. Islam is a dialogical religion". 58

"Suicide bombings are inhumane acts, and Allah does not like people who kill themselves, even less to kill others". ${ }^{59}$

"Suicide acts drive people to die in fäsiq". ${ }^{60}$

Based on the presented findings, it can be concluded that the pesantren teachers have a contrary understanding of the doctrines of terrorists. This also indicates their rejection of violent methods in achieving their goals.

\section{The Response of the Pesantren Students}

Regarding their understanding of jïhäd, fewer pesantren students $(\mathrm{n}=10)$ expressed their disapproval if jib äd should be understood as fighting the infidels and the polytheists. Some of them argued that jibäd does not only mean war but also doing good deeds such as learning. Furthermore, they stated that jibäd may also mean to broaden the mindset of the disbelievers and the polytheists, to fight the passions, to oppose the thoughts of the infidels and the polytheists who influence the Islamic world, and to carry out religious orders. The main purpose of jibäd, for some students, is to spread the teachings of Islam peacefully without coercion and violence as could be seen in these excerpts,

"Jihäd is not only fighting them (the infidels) but also the broad meaning of jibäd is to help the religion of Allah and including study hard;"61... "approaching Allah;"'62 ... "even a mother who died from childbirth is also categorized as jihäd". ${ }^{63}$

\footnotetext{
57 Interview with Denni Karo-karo (Mawaridussalam Islamic Boarding School Teacher) at Batangkuis on 7 June 2018.

58 Interview with Glen Sofyan (Mawaridussalam Islamic Boarding School Teacher) at Batangkuis on 21 March 2018.

${ }^{59}$ Interview with Azra Siltio (Mawaridussalam Islamic Boarding School Teacher) at Batangkuis on 21 March 2018.

60 Interview with Mufidatul Husna (Mawaridussalam Islamic Boarding School Teacher) at Batangkuis on 18 June 2018.

61 Interview with M. Duta Duanda (Mawaridussalam Islamic Boarding School student) at Batangkuis on 21 March 2018.
} 
However, the majority of the student participants $(n=18)$ agreed that jibäd means to fight the infidels and the polytheists. However, they specifically stated the infidels and the polytheists that should be fought against are those who fight Muslims at the first place. Based on the command of Qur'ān and hadìth about fighting the infidels and polytheists, they believed that jibäd should only be done when dealing with those who first fight the Muslims and invade Muslim lands. Thus, these findings indicate the different understanding of the pesantren students with that of the Islamists. The students understand jihad in the classical sense, whereas Islamists reinterpret the term.

Furthermore, the attitude of the pesantren students towards Jews and Israel is similar to that of the teachers as they agreed that Jews and Israel are enemies of Muslims. They consider that the Qur'ann and hadith have explained that Jews will never be happy with Islam and are always against Muslims. Their actions against the Palestinians are proof that they hate Muslims. Some of the states, "Jews and Israel are enemies of Muslims until the end of the day," "Jews are a group that hates Muslims and has already harmed Muslims in Palestine," ${ }^{65}$ and "in Palestine, they are people who do not have hearts and feelings". 66 Thus, it could be concluded that in this case, the students share a similar understanding with that of the Islamists.

Regarding the issue of suicide bombing, the majority of students $(n=24)$ agreed that suicide bombings are prohibited in Islam. They put forward the reason that suicide bombings, according to them, are wrongdoing and inhuman, and a manifestation of failure in understanding Islamic teachings. They also stated that suicide bombing is an act that brings sin and hated by Allah; thus suicide bomber will die fäsiq as what some of them said, "bombing vital objects belonging to the Western world are the characteristics of a

62 Interview with Khoirur Rozi dan Mhd. Latifudzikri (Mawaridussalam Islamic Boarding School student) at Batangkuis on 29 March 2018.

63 Interview with Syahreza Pahlevi dan Abdul Latif (Mawaridussalam Islamic Boarding School student) at Batangkuis on 21 March 2018.

${ }^{64}$ Interview with Abdul Latif (Mawaridussalam Islamic Boarding School student) at Batangkuis on 20 March 2018.

65 Interview with Khairani Amnur (Mawaridussalam Islamic Boarding School student) at Batangkuis on 20 March 2018.

${ }^{66}$ Interview with Fahmi Sultoni (Mawaridussalam Islamic Boarding School student) at Batangkuis on 20 March 2018. 
coward"; "67 "a culprit is a person who does not understand religion;" 68 "the act is an act of wrongdoing;" "69 "the culprit died in a fäsiq condition" $" 70$

Interestingly a small number of students $(n=4)$ agreed with the act of suicide bombings on vital objects of the Western world. According to them, bombing objects belonging to the West will give their fear of the Islamic world. This way, for some of them, is a way to advance the Islamic world, frighten enemies and save Islam from the insults of its enemies. A small number of students believed that the Western world ignores morality, so that violence must be used to make them aware as stated in this excerpt,

"The majority of Western people have done a lot of immorality, and are free in socializing and dressing". ${ }^{71}$

This shows that a small number of students have a radical understanding. However, this radical view could still be revised and straightened considering their age and status as students. Jihadist Islamist groups do accept violence, but institutional Islamism rejects the path of violence and prioritizes democratic ways in achieving goals.

\section{Concluding Remarks}

Based on the explanation and interpretation of the data above, the following two conclusions are drawn. First, the majority of teachers accept the idea of the establishment of an Islamic state and make Islamic law as a law in Indonesia. The majority of teachers accept the democratic system and believe that there is no conflict between Islam and democracy. However, despite accepting democracy, they reject the existence and recognition of minority groups such as LGBT, Shia, and Ahmadiyya. The majority of them also reject women's leadership and the concepts of secularism,

67 Interview with Mhd. Latifudzikri (Mawaridussalam Islamic Boarding School student) at Batangkuis on 20 March 2018.

68 Interview with Agung Ilham Syahputra (Mawaridussalam Islamic Boarding School student) at Batangkuis on 20 March 2018.

69 Interview with Khairani Amnur (Mawaridussalam Islamic Boarding School student) at Batangkuis on 20 March 2018.

${ }^{70}$ Interview with Annisa Rafika (Mawaridussalam Islamic Boarding School student) at Batangkuis on 24 March 2018.

71 Interview with Uswatun Chasanah (Mawaridussalam Islamic Boarding School student) at Batangkuis on 24 March 2018. 
pluralism, and liberalism. In terms of jihäd, the majority of the teachers accept that the meaning of jih äd is to fight the infidels and the polytheists, however, it only applies to those who initiate to fight Muslims. All teachers agree that Jews and Israel are enemies of Muslims and suicide bombings are not part of jibäd, thus the act needs to be prohibited.

Second, the majority of the students agreed with the idea of establishing an Islamic state and the enforcement of Islamic law as a law in Indonesia. They also accept the democratic system and agreed that there is no conflict between Islam and democracy. Furthermore, all students reject LGBT, secularism, pluralism, liberalism, and Shī'ah, but a small number of them do not oppose the existence of Ahmadiyah and women's leadership in a country. Regarding the issue of jibad, the majority of students agree that it means fighting the infidels and the polytheists who are hostile to Muslims. All students agreed that Jews and Israel are enemies of Muslims. The majority of them reject suicide bombings, but a small number agree with the act of bombing vital objects belonging to the West.

This study confirms that not all the understandings of the teachers and the students of Pesantren Mawaridussalam are identical with the understanding of Islamist and radical groups. There is a difference in their understanding regarding the issues of the Islamic state, sharī'ah, democracy, jïhäd and non-Muslims. Some of their opinions are identical to those of Islamists, but some others are not. They agreed that Jews were enemies of Muslims, and suicide bombings were prohibited acts in Islam. Regarding the issue of the Islamic state, Islamic law and democracy, the teachers and students differed from one another.

\section{Bibliography}

\section{A. Book and Article}

A `la, Abd., Zamzami, Mukhammad., Udin, Nur Hidayat Wakhid., Aniq, Ahmad Fathan. "Islamism In Madura: From Religious Symbolism to Authoritarianism", Journal of Indonesian Islam, Vol. 12, No. 2, 2018.

A'la, Abd., Mukarrom, Ahwan., Zamzami, Mukhammad. "Islam dan Agamaisasi Politik: Studi Analisis terhadap Peran dan Pergerakan Forum Kiai Muda (FKM) Pamekasan Madura", Jurnal Review Politik, Vol. 8, No. 1, 2018. 
-----. "Kontribusi Aliansi Ulama Madura (AUMA) dalam Merespons Isu Keislaman dan Keumatan di Pamekasan Madura", Religió: Jurnal Studi Agama-agama, Vol. 8, No. 2, 2018.

Adiwilaga, Rendy. "Gerakan Islam Politik dan Proyek Historis Penegakan Islamisme di Indonesia," Jumal Wacana Politik, Vol. 2, No. 2, 2017.

Akbar, Nuruddin Al. "Probabilitas Syariatisasi Negara Paska Orde Baru: Berkaca dari Strategi Kelompok Islamis Memperjuangkan Pengesahan RUU APP," Jurnal Sosiologi Islam, Vol. 3, No. 2, 2013.

Amal, Taufik Adnan and Panggabean, Syamsu Rijal. Politik Syariat Islam: dari Indonesia hingga Nigeria. Jakarta: Pustaka Alvabet, 2004.

Amiq. "Two Fatwas on Jihad Against the Ducth Colonialization in Indonesia: A Prosopographical Approach to the Study of Fatwa," Studia Islamika, Vol. 5, No. 3, 1998.

Areke, Lukman. "Pendekatan Hukum Islam terhadap Jihad dan Terorisme," Ulumuna: Journal of Islamic Studies, Vol. 16, No. 1, 2012.

Atmari. "Post-Islamism Kyai: Memantapkan Nalar dan Sikap Islamisme ala Intelektual Pesantren," in $2^{\text {nd }}$ Annual Conference for Muslim Scholar Proceedings, 2018.

Baharun, Hasan and Awwaliyah, Rabiatul. "Pendidikan Multikultural dalam Menanggulangi Narasi Islamisme di Indonesia," Jurnal Pendidikan Agama Islam, Vol. 5, No. 2, 2017.

Darmadji, Ahmad. "Pondok Pesantren dan Deradikalisasi Islam di Indonesia," Millah: Jurnal Studi Agama, Vol. XI, No. 122011.

Daulay, Haidar Putra. Pendidikan Islam dalam Sistem Pendidikan Nasional di Indonesia. Jakarta: Prenada, 2004.

-----. Sejarah Pertumbuban dan Pembaruan Pendidikan Islam di Indonesia. Jakarta: Prenada, 2012.

Dhofier, Zamakhsyari. Tradisi Pesantren: Studi Tentang Pandangan Hidup Kyai. Jakarta: LP3ES, 1982.

Fatimah, Ai and Fuad, Nur. "Islamisme dan Dakwah di Indonesia: Perspektif dan Pengalaman Dakwah Gerakan Tarbiyah," Komunika: Jurnal Komunikasi, Vol. 10, No. 1, 2015.

Harmakaputra, Hans Abdiel. "Islamism and Post-Islamism: "NonMuslim" in Socio-Political Discourse of Pakistan, the United States, and Indonesia," al-Jami'ah: Journal Islamic Studies, Vol. 53, No. 1, 2015. 
Hilmy, Masdar. "Konstruk Teologis Islamisme Radikal di Indonesia Pasca-Orde Baru," MIQOT: Jurnal Ilmu-ilmu KeIslaman, Vol 32, No 1, 2008.

-----. "The Politics of Retaliation: the Backlash of Radical Islamists to the Deradicalization Project in Indonesia," al-Jami'ab: Journal Islamic Studies, Vol. 51, No. 1, 2013.

Ismail, Faisal. "The Nahdlatul Ulama: Its Early History and Contribution to the Establishment of Indonesian State," Journal of Indonesian Islam, Vol. 5, No. 2, 2011.

Ja'far. "Al Jam'iyatul Washliyah dan Ideologi Islamisme di Indonesia," in Moch. Nur Ichwan and Muhammad Wildan (eds.), Islamisme dan Pos-Islamisme dalam Dinamika Politik Indonesia Kontemporer. Yogyakarta: SUKA-Press, 2019.

----. "Perkembangan Politik Islamisme Moderat Al Jam'iyatul Washliyah", Al-A'raf: Jurnal Pemikiran Islam dan Filsafat, Vol. 16, No. 2, 2019.

----. Biografi Ketua Umum Pengurus Besar Al Jam'iyatul Washliyah. Medan: Perdana Publishing, 2015.

-----. Tradisi Intelektual Al Washliyah: Biografi Ulama Kharismatik dan Tradisi Keulamaan. Medan: Perdana Publishing, 2015.

Jahroni, Jajang. "Modernisme dan Radikalisme Islam di Indonesia: Menafsirkan Warisan Muhammad 'Abduh dan Rashid Ridha", Studia Islamika, Vol. 11, No. 3, 2004.

Juhannis, Hamdan. "The Struggle for Formalist Islam in South Sulawesi: From Darul Islam (DI) to Komite Persiapan Penegakan Syariat Islam (KPPSI)". PhD Thesis--Australian National University, 2006.

Kafid, Nur. "Dari Islamisme ke Premanisme: Pergeseran Orientasi Gerakan Kelompok Islam Radikal di Era Desentralisasi Demokrasi," Masyarakat: Jurnal Sosiologi, Vol. 21, No. 1, 2016.

Kusmanto, Yuli et al. "Dialektika Radikalisme dan Anti-Radikalisme di Pesantren," Walisongo: Jurnal Penelitian Sosial Keagamaan, Vol. 23, No. 1, 2015.

Lukens-Bull, Ronald. "The Traditions of Pluralism, Accommodation, and Anti-Radicalism in the Pesantren Community", Journal of Indonesian Islam, Vol. 2, No. 1,2008.

Malik, Abdul et al. "Kultur Pendidikan Pesantren dan Radikalisme," Jurnal Pembangunan Pendidikan: Fondasi dan Aplikasi, Vol. 4, No. 2, 2016. 
Mas'ud, Abdurrahman. Dari Haramain Ke Nusantara: Jejak Intelektual Arsitek Pesantren. Jakarta: Kencana, 2006.

Mujab, M. "The Role of Pesantren on the Development Islamic Science in Indonesia," MIQOT: Jurnal Ilmu-ilmu Keislaman, Vol. 37, No. 2, 2013.

Mulyadi, Sukidi. "Violence under the Banner of Religion: The Case of Laskar Jihad and Laskar Kristus," Studia Islamika, Vol. 10, No. 2, 2003.

Mursalin, Ayub and Katsir, Ibnu. "Pola Pendidikan Keagamaan Pesantren dan Radikalisme: Studi Kasus Pesantren-pesantren di Provinsi Jambi," Kontekstualita, Vol. 25, No. 2, 2010.

Niam, Khoirun. "Nahdlatul Ulama and the Production of Muslim Intellectuals in the Beginning of $21^{\text {st }}$ Century Indonesia," Journal of Indonesian Islam, Vol. 11, No. 2, 2017.

Noor, Firman. "Leadership and Ideological Bond: PPP and Internal Fragmentation in Indonesia," Studia Islamika, Vol. 23, No. 1, 2016.

-----. "Moderate Islamic Fundamentalism: Understanding the Political Thinking of the Partai Keadilan Sejahtera (PKS)," Studia Islamika, Vol. 14, No. 3, 2007.

Nurdin, Faisal. "Memetakan Narasi Islamisme di Medan, Sumatera Utara: Investigasi terhadap Pola Penyebaran dan Penerimaan terhadap Radikalisme," Jurnal Ilmu Politik dan Komunikasi, Vol. 5, No. 2, 2015.

Rusli. "Indonesian Salafism on Jihad and Suicide Bombings," Journal of Indonesian Islam, Vol. 8, No. 1, 2014.

Schumann, Olaf. "Jihad for Whom?: The Radicalization of Religion as a Response to Political Oppression: From Turkish to Indonesian Islam," Journal of Indonesian Islam, Vol. 2, No. 2, 2008.

Siddik, Dja'far and Ja'far. Al-Ittibadiyah: Delapan Dasawarsa Menerangi Nusantara. Medan: Perdana Publishing, 2017.

Tasman. "al-Rādikālīyah al-Islāmīyah: Afkāruhā wa Harakatuhā fì Indūnisiyā al-Mu'āṣir," Studia Islamika, Vol. 16, No. 1, 2009.

Tibi, Bassam. Islam and Islamism. London: Yale University Press, 2012.

----. Islam dan Islamisme, terj. Alfathri Adlin. Bandung: Mizan, 2016.

Wahid, Din. "Pentas Jihad Gerakan Salafi Radikal Indonesia," Studia Islamika, Vol. 14, No. 2, 2007. 
Zada, Khamami. Islam Radikal: Pergulatan Ormas-ormas Islam Garis Keras di Indonesia. Jakarta: Teraju, 2003.

Zamzami, Mukhammad. "Kontribusi Forum Kiai Muda (FKM) Madura dalam Membangun Islamisme di Pamekasan", Proceeding of the International Conference on Muslim Society and Thought, 3-4 October 2017, Surabaya, Indonesia, 2017.

\section{B. Interview}

Interview with Abdul Latif (Mawaridussalam Islamic Boarding School student) at Batangkuis on 20 March 2018.

Interview with Agung Ilham Syahputra (Mawaridussalam Islamic Boarding School student) at Batangkuis on 20 March 2018.

Interview with Ana Nur Annisa (Mawaridussalam Islamic Boarding School student) at Batangkuis on 20 March 2018.

Interview with Ana Nur Annisa (Mawaridussalam Islamic Boarding School student) at Batangkuis on 17 March 2018.

Interview with Annisa Rafika (Mawaridussalam Islamic Boarding School student) at Batangkuis on 24 March 2018.

Interview with Azra Siltio (Mawaridussalam Islamic Boarding School Teacher) at Batangkuis on 8 August 2018.

Interview with Azra Siltio (Mawaridussalam Islamic Boarding School Teacher) at Batangkuis on 21 March 2018.

Interview with Denni Karo-karo (Mawaridussalam Islamic Boarding School Teacher) at Batangkuis on 7 June 2018.

Interview with Emsi Mawarisa Ginting (Mawaridussalam Islamic Boarding School Teacher) at Batangkuis on 18 June 2018.

Interview with Fahmi Sultoni (Mawaridussalam Islamic Boarding School student) at Batangkuis on 20 March 2018.

Interview with Glen Sofyan (Mawaridussalam Islamic Boarding School Teacher) at Batangkuis on 21 March 2018.

Interview with Hamid (Mawaridussalam Islamic Boarding School student) at Batangkuis on 17 March 2018.

Interview with Khairani Amnur (Mawaridussalam Islamic Boarding School student) at Batangkuis on 20 March 2018.

Interview with Khoirur Rozi dan Mhd. Latifudzikri (Mawaridussalam Islamic Boarding School student) at Batangkuis on 29 March 2018.

Interview with M. Duta Duanda (Mawaridussalam Islamic Boarding School student) at Batangkuis on 21 March 2018. 
Interview with Mhd. Latifudzikri (Mawaridussalam Islamic Boarding School student) at Batangkuis on 20 March 2018.

Interview with Mhd. Latifudzikri and Agung Ilham Syahputra (Mawaridussalam Islamic Boarding School student) at Batangkuis on 20 March 2018.

Interview with Mufidatul Husna (Mawaridussalam Islamic Boarding School Teacher) at Batangkuis on 18 June 2018.

Interview with Sivliana (Mawaridussalam Islamic Boarding School student) at Batangkuis on 23 March 2018.

Interview with Syahreza Pahlevi (Mawaridussalam Islamic Boarding School student) at Batangkuis on 17 March 2018.

Interview with Syahreza Pahlevi dan Abdul Latif (Mawaridussalam Islamic Boarding School student) at Batangkuis on 21 March 2018.

Interview with Uswatun Chasanah (Mawaridussalam Islamic Boarding School student) at Batangkuis on 24 March 2018.

\section{Internet}

"Komisi I Dukung BIN Awasi 3 Kampus yang Terindikasi Radikalisme," available at https:// news.detik.com, 28 April 2018.

"Sejarah Pendirian Ponpes Mawaridussalam," http://mawaridus salam.ponpes.id/sejarah-pendirian, diakses 12 September 2018.

"Struktur Organisasi di Pondok Pesantren Mawaridussalam," http://mawaridussalam.ponpes.id/struktur-sekolah. Diakses 12 September 2018. 